Original article

\title{
Electronic and electrochemical properties of a grid-like structure of $\mathrm{Zn}$ (II)
}

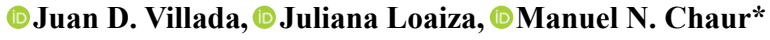 \\ Grupo SIMERQO, Departamento de Química, Universidad del Valle, Cali, Colombia
}

\begin{abstract}
A novel and highly soluble bis(hydrazone) was synthesized and characterized by different spectroscopic means. This compound was used as a ditopic ligand for the self-assembly of a grid-like complex using $\mathrm{Zn}^{2+}$ as metal cation. The structure of this compound was fully confirmed by NMR (1D and 2D). The electronic and electrochemical properties were studied using cyclic voltammetry, Osteryoung square wave voltammetry, and UV-Vis spectroscopy. The present work highlights the use of NMR spectroscopy as a tool to describe and analyse the formation of grid-like complexes based on the rotation of the phenyl group attached to the pyrimidine ring. Furthermore, the electrochemical results showed that the bis(hydrazone) 3 exhibits several different redox processes that are affected by the interaction with the metal cation as observed for the grid-like complex. Although the electrochemical processes are all irreversible, this article aims to be an initial study in the search for supramolecular complexes that can be used as electrochemical switches. (C) 2019. Acad. Colomb. Cienc. Ex. Fis. Nat.
\end{abstract}

Key words: Bis(hydrazones); Metallogrids; Supramolecular chemistry; Coordination chemistry.

Propiedades electrónicas y electroquímicas de una estructura del tipo de $\mathrm{Zn}$ (II)

\begin{abstract}
Resumen
Una nueva bis(hidrazona), altamente soluble en solventes orgánicos comunes, se sintetizó y caracterizó mediante diversas técnicas espectroscópicas. El compuesto se utilizó como ligando ditópico en la construcción de estructuras supramoleculares de tipo rejilla (rejillas supramoleculares o complejos metálicos de tipo rejilla) utilizando $\mathrm{Zn}^{2+}$ como catión metálico. El complejo supramolecular se confirmó mediante resonancia magnética nuclear $\mathrm{RMN}-{ }^{1} \mathrm{H}$ y bidimensional. El arreglo de tipo rejilla se determinó mediante las señales de $\mathrm{RMN}-{ }^{1} \mathrm{H}$ del anillo fenilo del ligando orgánico que cambia su velocidad de rotación y, por ende, su ambiente químico al coordinarse en dicho arreglo. Por último, se realizaron estudios de UV-Vis y voltamperometría cíclica y de onda cuadrada, con el fin de determinar las propiedades optoelectrónicas y electroquímicas de estos compuestos. Tanto la bis(hidrazona) como el complejo de tipo rejilla aquí presentados, exhiben varios potenciales de oxidación-reducción, los cuales se estudiaron en detalle mediante las técnicas mencionadas y cuyo estudio sirve de base para el desarrollo futuro de estructuras supramoleculares que puedan utilizarse como interruptores moleculares electroquímicos. (C) 2019. Acad. Colomb. Cienc. Ex. Fis. Nat.
\end{abstract}

Palabras clave: Bis(hidrazona); Rejillas supramoleculares; Química supramolecular; Química de coordinación.

\section{Introduction}

The miniaturization of functional materials used in different technological devices has been based on different "topdown" approaches. The findings in this field of research have resulted in the technological boom we now live in. However, given the imminent impossibility to obtain smaller materials, which would hinder technological development, several new approaches have started to gain attention in the scientific community. Based on the self-assembly of welldefined molecular pieces via covalent and non-covalent interactions (Lehn, 2006), supramolecular chemistry has attracted a lot of interest since its definition by Jean-Marie Lehn (Lehn, 1988) and has resulted in the construction of several functional materials, an evolution that reached its climax when the chemistry Nobel prize was awarded in 2016 to Sir Fraser Stoddard, Ben Feringa, and Jean-Pierre Sauvage for their work in "the design and synthesis of molecular machines" (Nobelprize.org, 2016).

The study of the self-assembly of different compounds has resulted in complex and well-defined structures such as catenanes (Wasserman, 1960), molecular knots (DietrichBuchecker \& Sauvage, 1989), macrocycles (Busch, 1967;

\footnotetext{
*Corresponding autor:

Manuel N. Chaur; manuel.chaur@correounivalle.edu.co

Received: December 27, 2018

Accepted: May 29, 2019

Editor: Luis Fernando Echeverri
} 
Curtis, 1960), and metallogrids (Hanan, et al., 1997; Ruben, et al., 2004). In this regard, grid-like metal ion arrays have gained an important place because of their welldefined structure and their interesting physical properties. Nowadays, there are several examples of the highly rich chemical properties of these compounds among which we can mention complexes that show spin crossover behavior (Breuning, et al., 2000; Shen, et al., 2016; Wu, et al., 2014), antiferromagnetic properties (Biswas, et al., 2014; Parween, et al., 2017), and magnetic coupling (Thompson, et al., 2005), multiple redox states (Ruben, et al., 2000; Uppadine, et al., 2005), and pH-dependent electronic properties (Ruben, et al., 2003). All of these, combined with the well-positioned metal ions in the organic matrix, make metallogrids a potential part of future memory devices, logic operators or write and read devices (Alam, et al., 2005).

The design of this grid-like supramolecular arrays by self-assembly requires the synthesis of ligands with the necessary information to arrange the metal cations (on a plane) in a square-like arrangement (Dawe, et al., 2009; Dawe \& Thompson, 2008; Harrowfield \& Lehn, 2012). Early examples of metallic grids employed different bidentate and tridentate ligands based on bi(pyridines) (Youinou, et al., 1992) and terpyridines (García, et al., 1999). However, due to their cumbersome synthesis and low yields, several groups shifted toward ligands with the core pyridinepyrimidine-pyridine connected by hydrazone moieties $(-\mathrm{C}=\mathrm{N}-\mathrm{N}-)$ (Ruben, et al., 2003).

Bis(hydrazones) have allowed the synthesis of different grid-like structures with a wide range of metal cations (Hardy, 2013; Stefankiewicz, et al., 2009). However, the solubility of these ligands tends to be low, affecting the grid formation and the yields of the final product. To solve this problem, recently, several bis(hydrazones) bearing alkyl groups have been reported, which increase the solubility of the ligand (and its complexes) in several organic solvents (for instance, chloroform, acetone, dimethylformamide, tetrahydrofuran, among others) (Carmona-Vargas, et al., 2017; Chaur-Valencia, et al., 2018) allowing full characterization in solutions. In this regard, herein we report the synthesis of a new bis(hydrazone) ligand with an orthophenylbutane substituent highly soluble in different common organic solvents. Spectroscopy characterization and its use in the synthesis of grid-like complexes using $\mathrm{Zn}^{2+}$ as metal cation is reported as well. We also render the full electrochemical characterization of the free ligand and the grid complex and a full NMR characterization of the complex. Our purpose was to increase the knowledge on this bis(hydrazone) ligands and their performance in the preparation of grid complexes.

\section{Experiments}

Materials and physical methods. All starting materials and solvents were purchased from Sigma-Aldrich ${ }^{\circledR}$ and used without further purification. The NMR (1D and 2D experiments), UV-Vis, fluorescence spectra, and elemental analysis were recorded on an NMR $400 \mathrm{MHz}$ Bruker UltraShield $^{\mathrm{TM}}$, a Pharma Spec Shimadzu JASCO V-730 UV-VIS spectrophotometer, a JASCO FP-8500 spectrofluorimeter, and a Thermo flashEA \#1112 series instrument with a $\mathrm{CHN}$ analyzer, respectively.

Synthesis of bis(hydrazone) (3) and $\mathrm{Zn}^{2+}$ metallogrid. 2-(4-butylphenyl)-4,6-dihydrazinylpyrimidine (2). $101.2 \mathrm{mg}$ of 2-(4-butylphenyl)-4,6-dichloropyrimidine (1) $(0.36 \mathrm{mmol}$ ${ }^{1} \mathrm{H}-\mathrm{NMR}$ on figure S1, https://www.raccefyn.co/index.php/ raccefyn/article/downloadSuppFile/822/3773) were mixed with an excess of monohydrated hydrazine $(1.0 \mathrm{~mL}, 20.6$ mmol) and refluxed for 6 hours under an inert atmosphere. Afterward, the excess of monohydrated hydrazine was removed from the desired product by reduced pressure. Compound (2) was obtained as a white powder with a $96 \%$ yield. ${ }^{1} \mathrm{H}-\mathrm{NMR}\left(400 \mathrm{MHz}, \mathrm{DMSO}-\mathrm{d}_{6}\right), \delta / \mathrm{ppm}: 8.18$ $(2 \mathrm{H}, \mathrm{d}, \mathrm{J}=8 \mathrm{~Hz}, \mathrm{H} 8), 7.55(2 \mathrm{H}, \mathrm{s}, \mathrm{H} 15) 7.24(2 \mathrm{H}, \mathrm{d}, \mathrm{J}=12$ $\mathrm{Hz}, \mathrm{H} 9), 5.98(1 \mathrm{H}, \mathrm{s}, \mathrm{H} 5), 3.18(4 \mathrm{H}, \mathrm{s}, \mathrm{H} 16), 2.64(2 \mathrm{H}, \mathrm{t}$, H11), 1.62-1.54 (2H, q, H12), 1.37-1.28 (2H, m, H13), 0.930.89 (3H, t, H14) (see Figures S2, https://www.raccefyn.co/ index.php/raccefyn/article/downloadSuppFile/822/3774). ${ }^{13} \mathrm{C}$ - NMR (101 MHz, DMSO-d $\left.{ }_{6}\right) \delta / \mathrm{ppm:} \mathrm{128.2,} \mathrm{128.0,}$ 35.2, 33.5, 22.3, 14.3 (see Figure S3, https://www.raccefyn. co/index.php/raccefyn/article/downloadSuppFile/822/3884 and S4, https://www.raccefyn.co/index.php/raccefyn/article/ downloadSuppFile/822/3885).

2-(4-butylphenyl)-4,6-bis((E)-2-(pyridin-2ylmethylene)hydrazinyl) pyrimidine (3). $90.6 \mathrm{mg}$ of compound $2(0.333 \mathrm{mmol})$ were added to $4 \mathrm{~mL}$ ethanolic solution of 2-pyridincarboxaldehyde $(0.07 \mathrm{~mL} 0.736 \mathrm{mmol})$ and the resulting solution was mixed under reflux for 8 hours. Then, the crude was concentrated using rotatory evaporation. The desired product 3 was obtained by precipitation using cold acetonitrile, filtered and recrystallized in ethanol with a $78 \%$ yield. M.p. $241-242{ }^{\circ} \mathrm{C} .{ }^{1} \mathrm{H}-\mathrm{NMR}\left(400 \mathrm{MHz}, \mathrm{CDCl}_{3}\right.$ ),

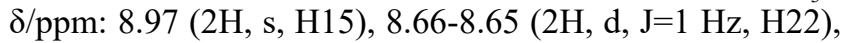
8.27-8.24 (2H, d, J=8 Hz, H8), 8.13-8.11 (2H, d, J=8 Hz, H19), 7.96 (2H,s, H17), 7.83-7.79 (2H, t, H20), 7.32-7.29 (4H, H9-H21), $7.14(1 \mathrm{H}, \mathrm{s}, \mathrm{H} 5), 2.70-2.66(2 \mathrm{H}, \mathrm{t}, \mathrm{H} 11)$, 1.67-1.59 (2H, q, H12), 1.43-1.33 (2H, m, H13), 0.97-0.93 (3H, t, H14) (Figure S2, https://www.raccefyn.co/index.php/ raccefyn/article/downloadSuppFile/822/3774). ${ }^{13} \mathrm{C}$ - NMR $\left(101 \mathrm{MHz}, \mathrm{CDCl}_{3}\right), \delta / \mathrm{ppm}: 149.5,142.3,136.4,128.6$, 127.9, 123.6, 120.4 (Figure S5, https://www.raccefyn.co/ index.php/raccefyn/article/downloadSuppFile/822/3886; and S6, https://www.raccefyn.co/index.php/raccefyn/article/ downloadSuppFile/822/3887). Elemental analysis for $\mathrm{C}_{26} \mathrm{H}_{26} \mathrm{~N}_{8} \mathrm{CH}_{3} \mathrm{CN}$; calculated percentage (\%): $\mathrm{C} 68.41 ; \mathrm{H}$ 5.95; N 25.64; percentage (\%) found: C 68.43; H 5.68; N 23.86.

Metallogrid $\left[\mathrm{Zn}_{4}(3)_{4}\right] \cdot\left(\mathrm{BF}_{4}\right)_{8} \cdot 20.8 \mathrm{mg}(0.046 \mathrm{mmol})$ of ligand 3 were added to a $5 \mathrm{~mL}$ round flask with $2.0 \mathrm{~mL}$ of $\mathrm{MeCN}$ under stirring. Then, a solution of $\mathrm{Zn}\left(\mathrm{BF}_{4}\right)_{2} \cdot 7 \mathrm{H}_{2} \mathrm{O}$ ( $16.9 \mathrm{mg}$ in $2 \mathrm{~mL}$ of $\mathrm{MeCN}$ ) was added dropwise to the stirring solution. After 24 hours, the initial suspension turned into a yellow solution. The complex was precipitated by the slow 
addition of diethylether and filtered for a $90 \%$ yield. M.p.: $>293{ }^{\circ} \mathrm{C} .{ }^{1} \mathrm{H}-\mathrm{NMR}\left(400 \mathrm{MHz}, \mathrm{MeCN}-\mathrm{d}_{3}\right.$ ), $\delta / \mathrm{ppm}: 7.88-7.84$ $(2 \mathrm{H}, \mathrm{t}), 7.77(2 \mathrm{H}, \mathrm{s}), 7.73-7.72(2 \mathrm{H}, \mathrm{d}, \mathrm{J}=4 \mathrm{~Hz}), 7.56-7.54(2 \mathrm{H}$, d, J=8 Hz), $7.38(1 \mathrm{H}, \mathrm{s}), 7.26-7.23(2 \mathrm{H}, \mathrm{t}), 6.91(1 \mathrm{H}, \mathrm{s}), 6.48$ $(1 \mathrm{H}, \mathrm{s}), 6.30(1 \mathrm{H}, \mathrm{s}), 5.44(1 \mathrm{H}, \mathrm{s}), 3.14-3.09(2 \mathrm{H}, \mathrm{t}), 2.07-$ $1.99(2 \mathrm{H}, \mathrm{q}), 1.85-1.77(2 \mathrm{H}, \mathrm{m}), 1.31-1.28(3 \mathrm{H}, \mathrm{t})$ (Figures S7, https://www.raccefyn.co/index.php/raccefyn/article/ downloadSuppFile/822/3888; S8, https://www.raccefyn.co/ index.php/raccefyn/article/downloadSuppFile/822/3889; and S9, https://www.raccefyn.co/index.php/raccefyn/article/ downloadSuppFile/822/3890). ${ }^{13} \mathrm{C}-\mathrm{NMR}\left(101 \mathrm{MHz}, \mathrm{CD}_{3} \mathrm{CN}\right)$,

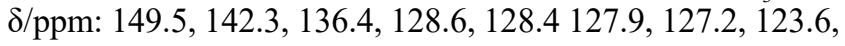
120.4. Elemental analysis: Calculated percentage (\%) for the molecular formula $\mathrm{C}_{104} \mathrm{H}_{138} \mathrm{~N}_{32} \mathrm{~B}_{8} \mathrm{~F}_{32} \mathrm{O}_{17} \mathrm{Zn}_{4}\left(\left[\mathrm{Zn}_{4}(3)_{4}\right]\right.$ $\left.\left(\mathrm{BF}_{4}\right)_{8} 17\left(\mathrm{H}_{2} \mathrm{O}\right)\right)$ : $\mathrm{C} 40.76 ; \mathrm{H} 4.54 ; \mathrm{N} 14.63$; percentage (\%) found: C 40.41; H 4.37; N 14.79 .

Electrochemical experiments. Osteryoung Square Wave Voltammetry (OSWV) and Cyclic Voltammetry (CV) were recorded on dry dimethylformamide (dried through common procedures) using a three-electrode system with silver wire as the pseudo-reference electrode, a platinum wire as the auxiliary electrode, and a glassy carbon as the working electrode. Peak potentials were referenced versus ferrocene. All the data were recorded on an Autolab PGSTAT302N potentiostat (Metrohm). CVs were measured in a range from $-2.5 \mathrm{~V}$ to $2.0 \mathrm{~V}$ in a scan rate of $100 \mathrm{mV} / \mathrm{s}$ with step potential of $0.01 \mathrm{~V}$ unless otherwise stated. OSWV measurements were carried out with a step potential of $0.005 \mathrm{~V}$, an amplitude of $0.005 \mathrm{~V}$, and a frequency of $20 \mathrm{~Hz}$.

\section{Results and discussion}

Synthesis of the organic ligand 2-(4-butylphenyl)-4,6bis((E)-2-(pyridin-2-ylmethylene) hydrazinyl) pyrimidine. The highly soluble bis(hidrazone) 3 required a 2-step synthetic pathway as shown in Figure 1. Compound 2 was obtained with a $96 \%$ yield by the nucleophilic aromatic substitution of compound $\mathbf{1}$ (used without further purification) using hydrazine monohydrate as nucleophile on an inert atmosphere after 8 hours; the excess of hydrazine was removed by rotatory evaporation and compound 2 was precipitated as a white solid by the continuous addition of diethyl ether.

Compound 2 turned out into a purple solid with the presence of oxygen. The rapid decomposition of 2 prevented its storage. For this reason, hydrazine 2 must be used immediately after preparation. To produce the target hydrazone 3,2 was dissolved in methanol with a drop of chloroform and stirred until it was completely dissolved. Then, pyridinecarboxaldehyde ( 2.2 equivalents) was added dropwise to the solution. After 8 hours of reflux, a yellow solid appeared in the bulk of the reaction. The solid was filtered and recrystallized in ethanol to obtain the bis (hydrazone) 3 as a white solid with $76 \%$ yield.

The ${ }^{1} \mathrm{H}-\mathrm{NMR}$ of compounds 2 showed the presence of the alkyl protons at high field. Additionally, at low field, in the aromatic region, the hydrazine 2 presented two doublets at 8.18 and $7.24 \mathrm{ppm}$ that integrate for two protons each. The correlation between these two signals is common for substituting aromatic rings, which allowed us to assign the two signals to protons 8 and 9 of the anisole ring. Another feature of this compound is the presence of the hydrazine $\mathrm{NH}$ protons that appear as two singlets at 7.55 and $3.18 \mathrm{ppm}$ (H-15, H-16). These signals integrated for 2 and 4 protons, respectively, which confirmed the double substitution of the chloride precursor.

Bis(hydrazone) 3 was also analyzed by ${ }^{1} \mathrm{H}-\mathrm{NMR}$ means. As was expected, the high field signals present in compound 3 underwent almost no change compared with its precursor 2. Downfield, in the aromatic region, five new signals corresponding to the new pyridine ring and the imine proton can be seen. It is important to note the shift to the lower field of the amine protons (H-15) due to the presence of the hydrazone double bond. NOESY experiments show a spatial correlation between protons $\mathrm{H}-17$ and $\mathrm{H}-15$, which corresponds to the amine and imine protons, respectively; this correlation is a clear indication of a transoid con-formation common for this kind of bis(hydrazones) (Stefankiewicz, et al., 2013).

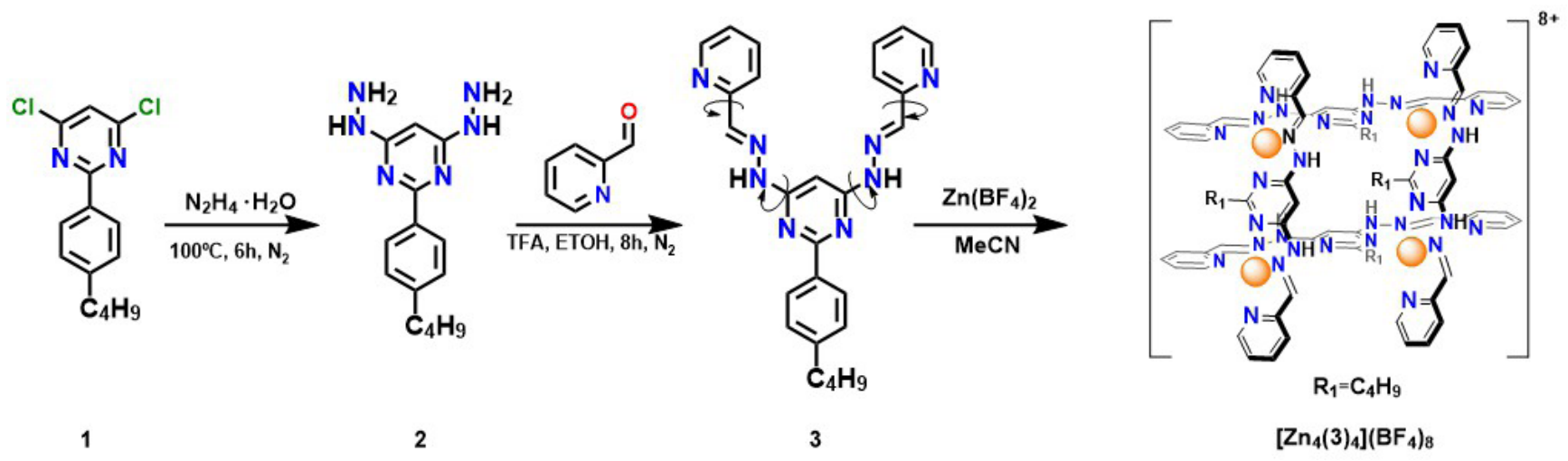

Figure 1. Synthetic route of the grid-like complex $\left[\mathrm{Zn}_{4}(3)_{4}\right]\left(\mathrm{BF}_{4}\right)_{8}$. Structure 3 must go through single-bond rotations (indicated with arrows) in order to accommodate the tridentate pockets for coordination. 
Characterization of the grid-like complex. Grid-like complexes are constructed by the self-assembly of polytopic organic ligands with metal cations that allow octahedral or, in some cases, a square planar geometry. In certain cases, it is possible that the formation of the grid complexes competes with other structures like helicates (Stadler, et al., 2016), racks (Stadler, et al., 2006) and corner-like structures (Stefankiewicz, et al., 2010). To prevent this kind of competition it is important to pay special attention to external factors like the solvent, the counter ion of the metal salt, and the stoichiometric between the metal cation and the organic ligand. In this work, we approached a synthetic methodology (Ruben, et al., 2006) using $\mathrm{Zn}\left(\mathrm{BF}_{4}\right)_{2}$ as the source for the metal cation. $\mathrm{Zn}^{2+}$ is a well-known cation in the construction of supramolecular grid-complexes thanks to its diamagnetic behavior, which allows the characterization of its complexes by NMR spectroscopy (Barboiu, et al., 2006). Furthermore, different anions have shown a templating effect on the formation of certain supramolecular structures (Hasenknopf, et al., 1997). Particularly in the construction of grid-like complexes with $\mathrm{Ni}^{2+}$ and $\mathrm{Zn}^{2+}$, anions like $\left(\mathrm{BF}_{4}\right)^{-}$and $\mathrm{ClO}_{4}^{-}$have led to the formation of the desired [2x2] arrangements over bigger ones which have resulted in different assemblies (Bu, et al., 2000; CamposFernández, et al., 2001).

Ligand 3 and the salt of $\mathrm{Zn}^{2+}$ were mixed with a 1:1 stoichiometric relation in acetonitrile. In the first minutes of the reaction, the stirring crude appeared as a suspension, then turned into a yellow solution thanks to the formation of the grid complex. The reaction was left to stir for 24 hours to ensure the formation of the most stable structure under our experimental conditions. Thereafter, the grid-like complex was precipitated using diethyl ether and filtered to obtain a yellow solid with a $90 \%$ yield.

NMR spectroscopy was used to follow the changes and shifts in the signals of the organic components of the complex. Figure 2 shows the ${ }^{1} \mathrm{H}-\mathrm{NMR}$ spectrum of the grid compound $\left[\mathrm{Zn}_{4}(3)_{4}\right]\left(\mathrm{BF}_{4}\right)_{8}$. The signals in the high field did not present much change in comparison with the uncomplexed ligand $\mathbf{3}$. This similarity could be an indication of the position of the aliphatic chains outside of the grid structure. On the other hand, the analysis of the aromatic region of the spectrum shows four new signals at 5.47, $6.47,6.89$, and $7.45 \mathrm{ppm}$. To fully understand the nature of these new signals, a bidimensional COSY NMR experiment was carried out (Figure 3) showing a correlation between the signals at $6.89-5.47 \mathrm{ppm}$ and at $6.45-7.45 \mathrm{ppm}$. Such correlations (Figure 2) correspond to the protons of the phenyl group in position 2 of the pyrimidine ring.

In the free ligand, the phenyl ring rotates freely around the pyrimidine-phenyl single bond axis (Figure 4). This rotation creates a similar chemical environment for the protons closer to the pyrimidine $\mathrm{H}_{8 \mathrm{e}}$ and $\mathrm{H}_{8 \mathrm{i}}$. Similar behavior was observed for the protons in the ortho position to the aliphatic chain $\mathrm{H}_{-{ }_{9 e}}$ and $\mathrm{H}_{9 \mathrm{i}}$. As a result of this rotation, the ${ }^{1} \mathrm{H}-\mathrm{NMR}$ of the free ligand show two signals, a doublet and a multiplet, that integrate each of them for two protons. On other hand, in the grid complex, the phenyl ring of the bis(hydrazone) ligands inserts itself between two ligands (Figure 3) parallel to the coordination pocket. The position of the phenyl ring inside the compact grid structure creates a steric hindrance that limits the rotation around the phenylpyrimidine bond. This behavior results first in the shielding of the inside protons of the phenyl ring shifting the signals up to $5.43 \mathrm{ppm}$ and finally results in the non-equivalence of the phenyl protons (Rojo, et al., 1999). Phenyl substituents in the position 2 of the pyrimidine ring are amongst the most used in the construction of grid complexes. Their presence allow several $\pi-\pi$ interactions that stabilize the structure (Dutta, et al., 2011)

The amount of information related in the bidimensional experiments agreed with other grid complexes reported in the literature (Barboiu, et al., 2006; Stefankiewicz, et al., 2010), which allowed us to confirm that our complex exhibited a grid structure in solution as shown in Figure S10, https://www.raccefyn.co/index.php/raccefyn/article/ downloadSuppFile/822/3891; in which the phenyl group

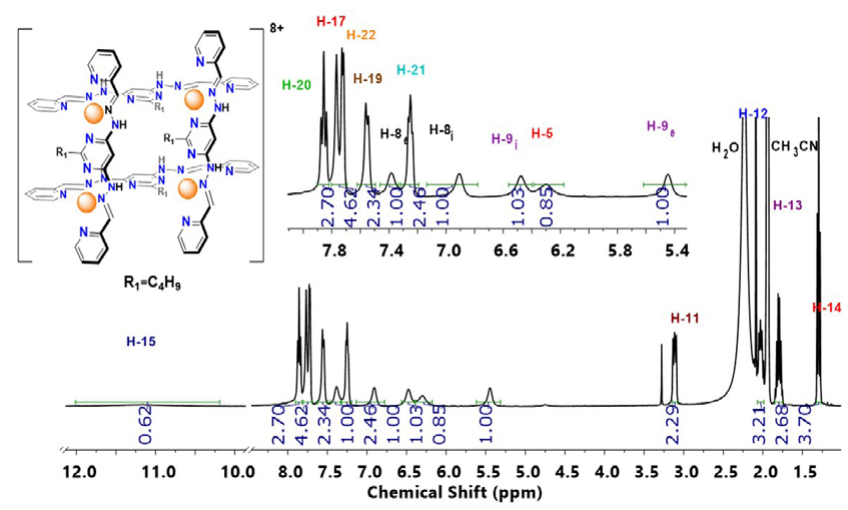

Figure 2. ${ }^{1} \mathrm{H}-\mathrm{NMR}$ of the grid complex $\left[\mathrm{Zn}_{4}(3)_{4}\right]\left(\mathrm{BF}_{4}\right)_{8}(400 \mathrm{MHz}$, CDCN)

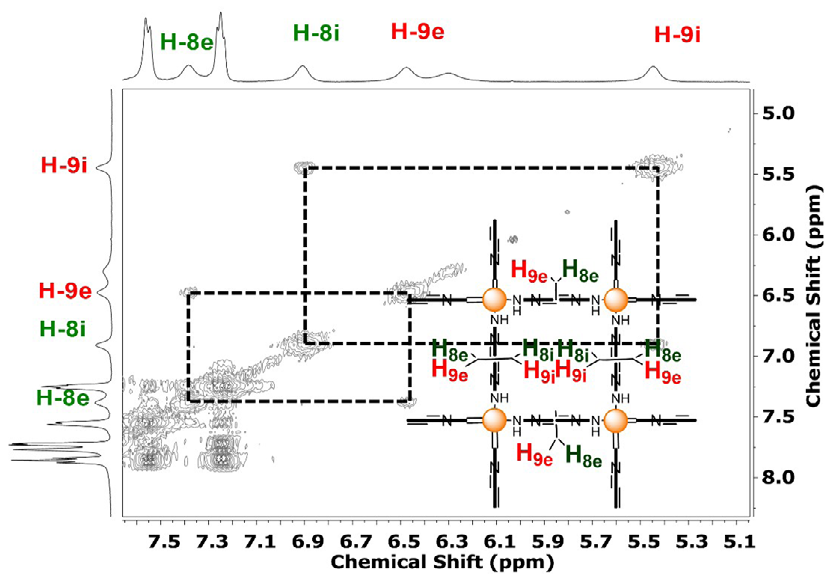

Figure 3. COSY spectrum of the grid complex $\left.\left[\mathrm{Zn}_{4}(3)\right)\right]\left(\mathrm{BF}_{4}\right)_{8}$ $\left(400 \mathrm{MHz}, \mathrm{CD}_{3} \mathrm{CN}\right)$ 


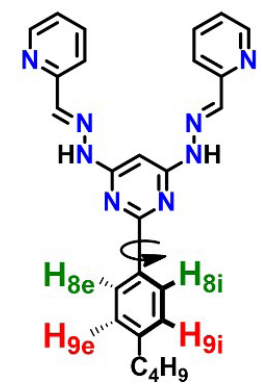

Free rotation of the phenyl group

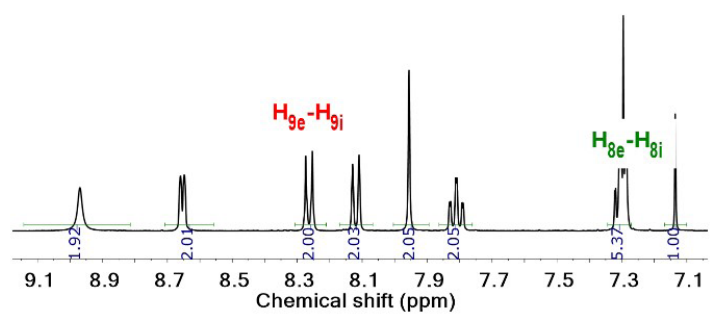

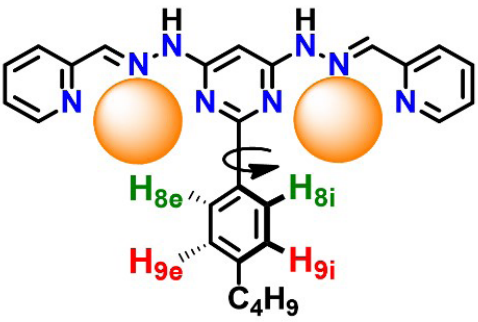

Steric effects on the grid complex slows the Rotation of the phenyl group

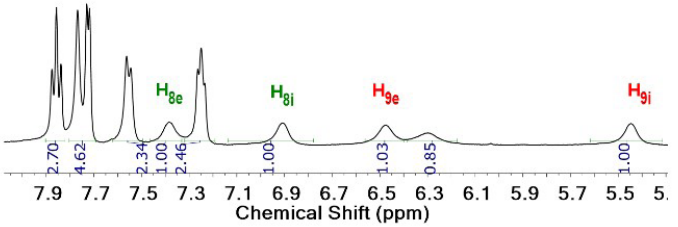

Figure 4. Representation of the steric hindrance of the phenyl group inside the grid complex

attached to the pyrimidine ring is right inside the grid structure and the aliphatic chains are organized in the outside of the structure. The elemental analysis for the grid-like compound with the molecular formula $\left(\left[\mathrm{Zn}_{4}(\mathbf{3})_{4}\right]\right.$ $\left(\mathrm{BF}_{4}\right)_{8} 17\left(\mathrm{H}_{2} \mathrm{O}\right)$ ) resulted in $\mathrm{C} 40.76 \%, \mathrm{H} 4.54 \%$, and $\mathrm{N}$ $14.63 \%$, which is consistent with the calculated one, further confirming the grid-like complex in the bulk.

The UV-Vis spectrum of the metal grid complex and the organic ligand $\mathbf{3}$ were taken using methanol as solvent. The free ligand 3 exhibited a broad absorption band from 235 to $350 \mathrm{~nm}$ (Figure S11, https://www.raccefyn.co/index. php/raccefyn/article/downloadSuppFile/822/3892). This band, which is common in hydrazone systems, corresponds to $\pi-\pi^{*}$ transitions present in the imine bond $(\mathrm{C}=\mathrm{N})$ of the hydrazone moiety and the ones found in the pyridine and pyrimidine rings (Wang, et al., 2010; Yu, et al., 2016). In contrast with the free ligand, the $\mathrm{Zn}^{2+}$ grid complex exhibited two bands in the visible region corresponding to the abovementioned $\pi-\pi^{*}$ transitions; the bathochromic shift present in the complex can be explained by the extended conjugation in the grid structure (Stefankiewicz, et al., 2009).

Redox behavior. To fully understand the redox behavior of ligand 3 and the grid complex $\left[\left(\mathrm{Zn}_{4}(3)_{4}\right]\left(\mathrm{BF}_{4}\right)_{8}\right.$ we conducted Cyclic Voltammetry (CV) and Osteryoung Square Wave Voltammetry (SWV) experiments.

Cyclic voltammograms of compound 3 and grid complex $\left[\left(\mathrm{Zn}_{4}(3)_{4}\right]\left(\mathrm{BF}_{4}\right)_{8}\right.$ are shown in Figure 5. Cathodic and anodic potentials were swept in different experiments; the arrows in the figure indicate both the beginning of the sweep and its initial direction. After the study was completed, ferrocene was added to the solution as an internal standard. The anodic CV curve of compound $\mathbf{3}$ (upper trace) presented an oxidation wave starting at $0.72 \mathrm{~V}$; this process did not

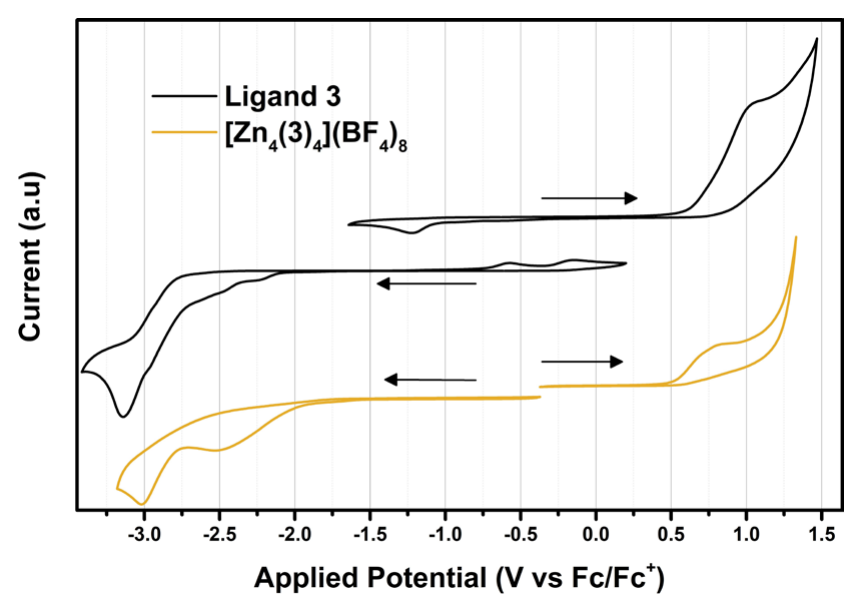

Figure 5. Cyclic voltammograms of compound $\mathbf{3}$ and the metallic grid complex $\left[\left(\mathrm{Zn}_{4}(3)_{4}\right]\left(\mathrm{BF}_{4}\right)_{8}\right.$ in DMF. Arrows show the initial voltage and the direction of the sweep. Scan rate: $100 \mathrm{mVs}^{-1}$

exhibit a well-defined re-reduction wave showing that it is an irreversible process. However, a reduction peak was observed at $-1.23 \mathrm{~V}$, which was not observed when the sweep was initiated to cathodic potentials. Most likely, when compound $\mathbf{3}$ is oxidized, a side reaction may occur generating a stable species which is reduced at $-1.23 \mathrm{~V}$. The latter is deduced from the shape of the wave and its current intensity. Increasing the speed rate shifted this reduction peak to more cathodic potentials and increased its current intensity (Figure 6).

This phenomenon was not observed on the $\mathrm{Zn}^{2+}$ grid complex, which could be an indication that the oxidized species of the grid complex are less stable than the ones formed with the free ligand, even if both are apparently 

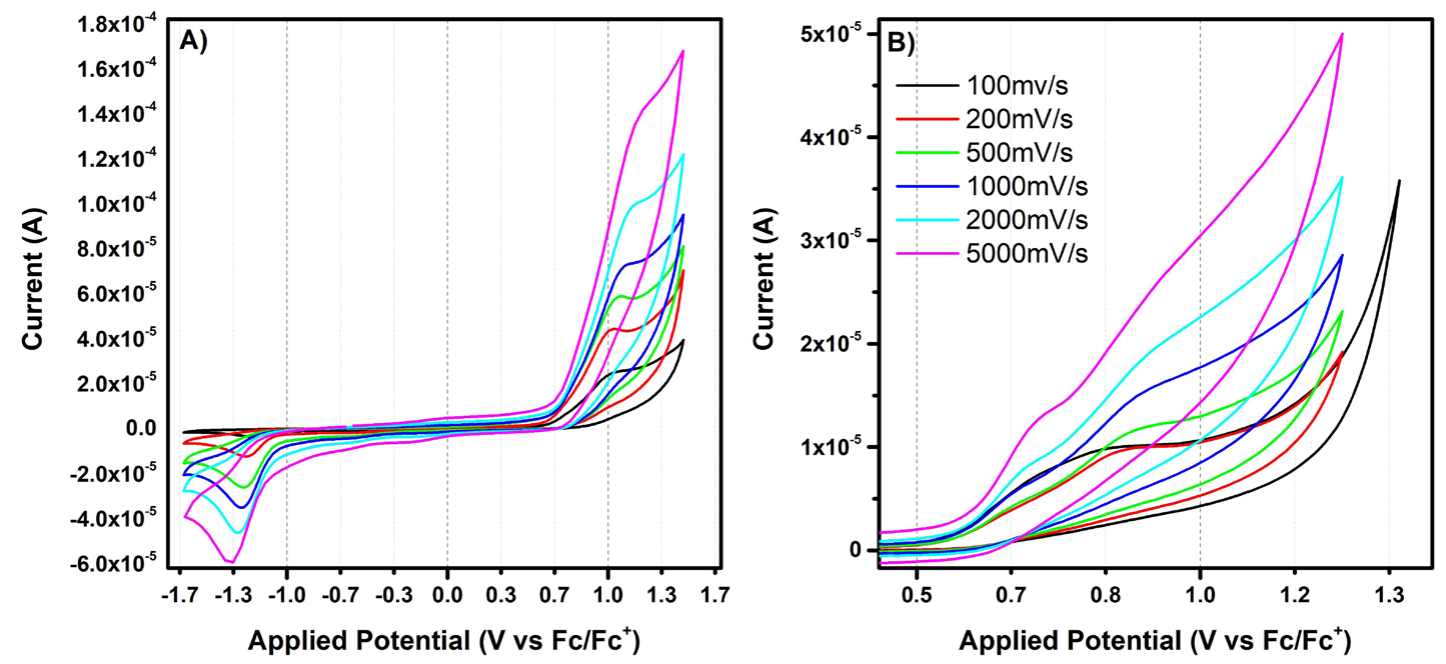

Figure 6. Cyclic voltammograms at different scan rates of (A) the oxidation processes in the free ligand $\mathbf{3}$ and (B) the grid complex $\left[\left(\mathrm{Zn}_{4}(3)_{4}\right]\left(\mathrm{BF}_{4}\right)_{8}\right.$

related to the organic structure of the compounds considering that the $\mathrm{Zn}^{2+}$ is electrochemically inactive within the studied potential window.

The complexation of $\mathbf{3}$ with $\mathrm{Zn}^{2+}$ results in a cathodic shift of $70 \mathrm{mV}$ for the oxidation process compared with the free ligand. This oxidation process in different hydrazones has been related to deprotonation of the N-H group in the hydrazone moiety (Gordillo, et al., 2017; (Adenier, et al., 2004). In the grid complex, the kinetics of the deprotonation of this group is faster due to the stabilization of the resulting negative charge by the $\mathrm{Zn}^{2+}$ cation and the extended conjugation of the structure.

On the other hand, the cathodic CV curve of compound 3 showed three reduction events that are irreversible in nature. The first two reduction processes presented areas of similar size and shape indicating that they may have the same number of electrons involved in the process. Contrary to this, the third reduction of $\mathbf{3}$ presented a bigger area compared to the first two reductions, which can be translated into more electrons associated with this reduction (Figure 4). The re-oxidation potentials of compound 3 coupled to the two first reduction steps were anodically shifted compared to the reduction potentials. The first two reduction events on molecule 3 exhibited two re-oxidations that were significantly shifted to more anodic voltages. The high kinetical barrier of this re-oxidation process could mean that the reduction of compound $\mathbf{3}$, at least in its first two reduction steps, is coupled to a chemical reaction. Furthermore, we can assure that these oxidation potentials are coupled to the reduction since they only appeared in the cathodic curve of the CV.

As mentioned before, the $\mathrm{CV}$ of compound $\mathbf{3}$ exhibited two smaller oxidation waves when starting the sweep in the cathodic direction. These processes that are associated with the first and second reduction events of the compound, showed an increase in the peak current when the second reduction took place at larger scan rates. When the same experiment was carried out for the third reduction peak, the oxidations not only increased their peak currents but also started to overlap. Besides, the peak potentials shifted cathodically implying a change in the electron transfer mechanism.

For the complex, the CV showed two reduction events around $-2.5 \mathrm{~V}$ and $-3.0 \mathrm{~V}$, both irreversible (Figure 4).

OSWV experiments (Figure 7) were carried out for compound 3 and the $\mathrm{Zn}^{2+}$ grid complex. The OSWV of compound 3 showed two oxidation peaks at 0.64 and 0.88 $\mathrm{V}$, which were very close and not very well-defined due to the overlapping of both waves. For compound $\mathbf{3}$ and for the grid complex, probably adsorption of the sample over the working electrode caused this closed double peak.

On the other hand, the OSWV showed three reduction events for $\left[\left(\mathrm{Zn}_{4}(3)_{4}\right]\left(\mathrm{BF}_{4}\right)_{8}\right.$ and the free ligand 3. Particularly, the cathodic $\mathrm{CV}$ of the grid complex showed two reduction events at $-2.5 \mathrm{~V}$ and $-3.0 \mathrm{~V}$; as can be seen in the OSWV

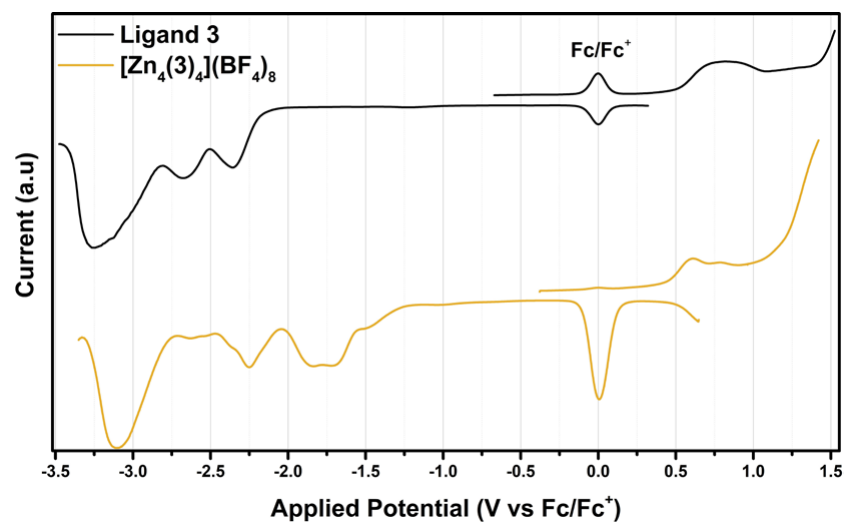

Figure 7. Osteryoung Square Wave Voltammograms of compound 3 and the grid complex $\left[\left(\mathrm{Zn}_{4}(3)_{4}\right]\left(\mathrm{BF}_{4}\right)_{8}\right.$ 
(Figure 5), the first event in the $\mathrm{CV}$ was composed of two separated reductions at -1.7 and $2.25 \mathrm{~V}$. The three reduction waves present in the grid complex are anodically shifted compared to the ones of the free ligand, an indication that the reduction processes are favored by the presence of the metal cation $\left(\mathrm{Zn}^{2+}\right)$, even if the metal used was not electrochemically active in the window of our experiments. The presence of the positive charged ions and the highly conjugated systems of the bis(hydrazone) ligands could add more stabilization to the electrons added to the molecule. It is interesting that the grid complex did not present the reduction events on the anodic curve and the oxidation events on the cathodic curve that can be seen on the free ligand. Their absence could be an indication that the mechanism of the transfer process changes from the free ligand to the grid complex.

The electrochemical events of the synthesized bis (hydrazone) 3 and its grid complex $\left[\mathrm{Zn}_{4}(3)_{4}\right]\left(\mathrm{BF}_{4}\right)_{8}$ were compared to other bis(hydrazones) and different grid- and rack-like complexes synthesized in our group (Table 1). The analysis of the different bis(hydrazones) showed a marked difference in the voltammetry potentials among them. Our compound $\mathbf{3}$ presented the first reduction peak at the most negative potential indicating that the addition of heteroatoms (compounds $\mathbf{7}$ and $\mathbf{8}$ in Table 1) had a marked effect on the ability of the organic compound to receive and stabilize electrons. It is also interesting that lower reduction potentials came from compounds without the phenyl ring at position 2 of the pyrimidine ring, which is an indication of the low participation of this substituent in the reduction mechanism of these compounds.

It is evident that metal complexation also has an influence on the electrochemical properties of these bis(hydrazone) compounds. In all cases, complexes exhibit reduction potentials anodically shifted when compared with the free ligands. The magnitude of the shift is dependent on the nature of the metal cation. For instance, electrochemically active cations like $\mathrm{Co}^{2+}$ and $\mathrm{Fe}^{2+}$ present lesser negative potentials than the complexes of electrochemically inactive cations like $\mathrm{Zn}^{2+}$ (Uppadine, et al., 2005). Electrochemical band gaps are also affected by the interaction between the ligand and the different metal cations. In fact, complexes exhibit smaller band gaps than the free bis(hydrazone).

To explore the nature of the different redox potentials, a series of CVs were recorded at different scan rates. Using the Randless-Sevick equation (Equation 1) a graph of peak current versus the square root of the scan rate was plotted to verify whether the electrochemical processes were controlled by diffusion or not. All events in compound 3 and the grid complex exhibited a linear correlation between peak current vs square root of the scan rate $\left(\mathrm{R}^{2}\right.$ of 0.99, approx.) (see Figure S12, https://www.raccefyn. co/index.php/raccefyn/article/downloadSuppFile/822/3893 and S13, https://www.raccefyn.co/index.php/raccefyn/ article/downloadSuppFile/822/3894), indicating a diffusion dependence and, therefore, fast electron transfer processes.

$$
\mathrm{i}_{\mathrm{p}}=2.99 \times 10^{5} \mathrm{nAC}(\alpha \mathrm{nDv})^{\frac{1}{2}} \quad \text { (Eq. 1). }
$$

Cyclic voltammetry at different scan rates can be used to analyze the behavior of the electron transfer processes in the redox events. The oxidation of $\mathbf{3}$ and the grid complex shows different behaviors when analyzed at different scan rates. On one side, ligand $\mathbf{3}$ shows an increase in the current as a function of the scan rate. Also, the peak potential of the oxidation wave shifts towards more positive potentials. The reduction wave connected to this oxidation process also exhibits an increase in its peak current at faster scan rates. It is possible that this reduction wave corresponds to the reduction of an electrochemically active species generated in the oxidation of the ligand (possible by the Electron Transfer-Chemical Reaction mechanism) which explains the differences in peak currents between the peaks.

Table 1. Peak potentials for the cathodic and anodic events of the compounds prepared and similar ones reported in the literature

\begin{tabular}{|c|c|c|c|c|c|c|c|}
\hline Compound & Reference & $\mathbf{E}_{\mathrm{p}, \text { Oxd (1) }}$ & $\mathbf{E}_{\mathrm{p}, \text { Oxd (2) }}$ & $\mathbf{E}_{\mathrm{p}, \operatorname{Red}(\mathbf{1})}$ & $\mathbf{E}_{\mathrm{p}, \operatorname{Red}(2)}$ & $\mathbf{E}_{\mathrm{p}, \operatorname{Red}(3)}$ & $\Delta \mathbf{E}(\mathbf{V})$ \\
\hline 3 & Present work & 0.72 & 0.92 & -2.34 & -2.67 & -3.26 & -3.28 \\
\hline$\left[\mathrm{Zn}_{4}(3)_{4}\right]\left(\mathrm{BF}_{4}\right)_{8}$ & Present work & 0.65 & 0.83 & -1.75 & -2.26 & -3.10 & -2.47 \\
\hline 4 & (Chaur-Valencia, et al., 2018) & 0.67 & 0.84 & -1.10 & -1.32 & -2.29 & -1.77 \\
\hline$\left[\mathrm{Co}_{4}(4)_{4}\right]\left(\mathrm{BF}_{4}\right)_{8}$ & (Chaur-Valencia, et al., 2018) & 0.66 & 0.79 & -0.57 & -1.11 & -1.27 & -1.23 \\
\hline 5 & (Fernández, et al., 2015) & 0.59 & - & -2.23 & - & - & -2.82 \\
\hline$\left[\mathrm{La}_{2}\left(\mathbf{5}^{-2}\right)\right] \mathrm{Cl}_{2}$ & (Fernández, et al., 2015) & 0.67 & - & -1.36 & - & - & 2.03 \\
\hline 6 & (Carmona-Vargas, et al., 2017) & 0.69 & - & -2.33 & -2.59 & - & 3.02 \\
\hline$\left[\mathrm{Zn}_{2}(\mathbf{6})\right] \mathrm{Cl}_{2}$ & (Carmona-Vargas, et al., 2017) & 0.58 & - & -1.43 & -1.99 & -2.41 & 1.16 \\
\hline 7 & (Carmona-Vargas, et al., 2017) & 1.00 & 1.18 & -1.09 & -1.30 & - & 2.09 \\
\hline$\left[\mathrm{Zn}_{2}(7)\right] \mathrm{Cl}_{2}$ & (Carmona-Vargas, et al., 2017) & 1.05 & 1.28 & -0.35 & -0.60 & - & 1.40 \\
\hline$\left[\mathrm{Zn}_{4}(7)_{4}\right] \mathrm{Cl}_{8}$ & (Carmona-Vargas, et al., 2017) & 0.58 & 0.86 & -1.22 & -2.28 & 2.50 & 1.80 \\
\hline
\end{tabular}

*Peak potentials are present as such due to the irreversibility of the events and are reported vs ferrocene.

$* * \Delta \mathrm{E}$ in volts calculated by the difference between the first oxidation potential and the first reduction potential 

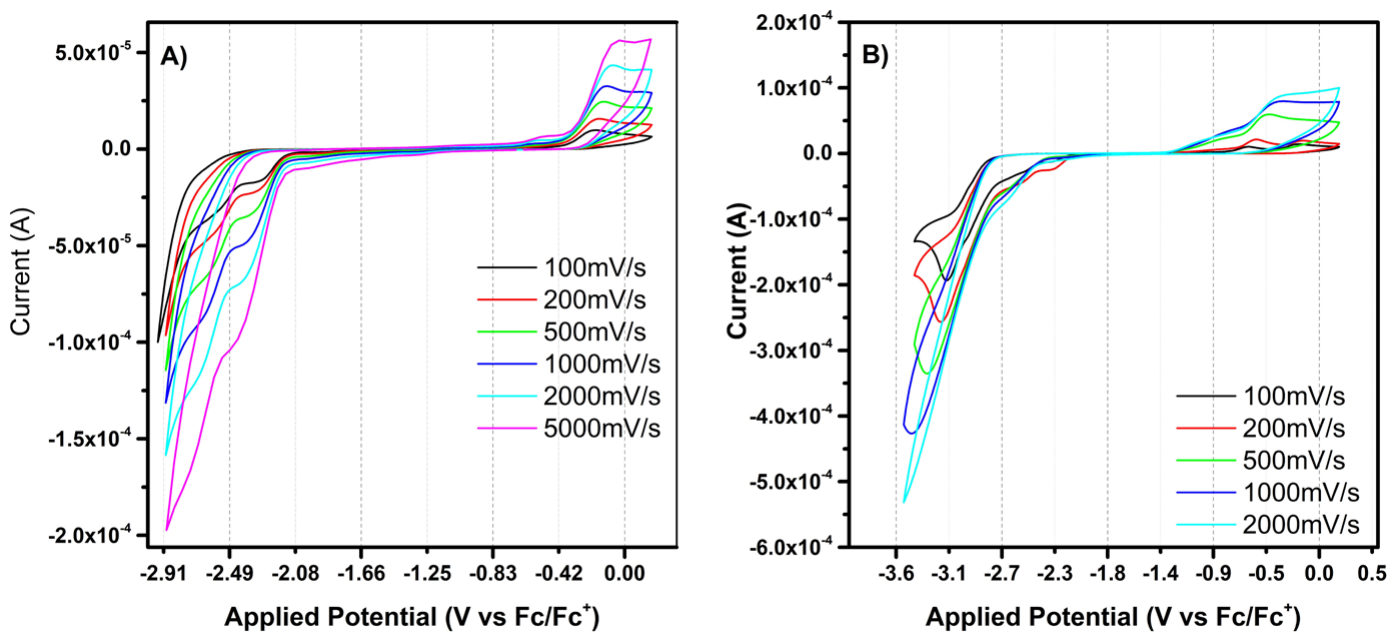

Figure 8. Cyclic voltammograms at different scan rates of the reduction processes in the free ligand 3. A) First two reduction events. B) Full cathodic curve

Interestingly, grid complex $\left[\left(\mathrm{Zn}_{4}(3)_{4}\right]\left(\mathrm{BF}_{4}\right)_{8}\right.$ shows the separation of the oxidation wave into two different processes that separate from each other as the scan rate increases (Figure 5). A presumable electron transfer mechanism could be involved in this redox process. A similar approach was used to analyze the reduction processes on ligand $\mathbf{3}$. In cathodic processes, the increase of the scan rate results in larger peak currents and a shift of the peak potentials to more cathodic potentials (Figure 8).

\section{Conclusions}

A new bis(hydrazone) 3 with a $p$-butylphenyl substituent in position two of the pyrimidine ring was successfully synthesized. This compound exhibits a remarkable solubility in common organic solvents. The bis(hydrazone) was then tested for the preparation of metal grid complexes using $\mathrm{Zn}\left(\mathrm{BF}_{4}\right)_{2}$. The ${ }^{1} \mathrm{H}-\mathrm{NMR}$ of the $\mathrm{Zn}^{2+}$ showed four individual signals for the phenyl protons due to the steric effects related to the position of this substituent in the supramolecular structure confirming the formation of the target metal grid structure. Electrochemical and UV-Vis analyses were carried out to characterize the electronic properties of the prepared compounds. The electrochemical analysis shows that the grid complex can accept multiple electrons. Further analysis also showed that the metal cation had a modular effect on the redox processes. In fact, each redox potential is anodically shifted in the grid structure compared to the free ligand. Finally, it was established that the metal cation also affects the electron transfer mechanism of the redox processes.

\section{Supplementary material}

We supply further details on the bidimensional NMR and the ${ }^{13} \mathrm{C}$-NMR spectra of the bis(hydrazone) 3 and the grid complex. Additionally, we provide complete RandlessSevick linearization for every redox potential found for the bis(hydrazone) and the $\mathrm{Zn}^{2+}$ complex.

\section{Acknowledgments}

The authors greatly thank the Vicerrectoria de Investigaciones and the Centro de Excelencia en Nuevos Materiales (CENM) of the Universidad del Valle for the financial support in the development of this research. JDV and MN also acknowledge Colciencias for the Grant "Jovenes investigadores para la paz" 2017, code FP44842-407-2017. Finally, the authors are grateful to Professor Alejandro Ortiz from Universidad del Valle for allowing them to use the potentiostat for the electrochemical experiments.

\section{Supporting information}

Figure S1. ${ }^{1} \mathrm{H}-\mathrm{NMR}\left(\mathrm{CDCl}_{3}, 400 \mathrm{MHz}\right)$ spectrum of 2-(4-butylphenyl) -4,6-dichloropyrimidine (1). See the figure S1 in: https://www. raccefyn.co/index.php/raccefyn/article/downloadSuppFile/822/3773

Figure S2. ${ }^{1} \mathrm{H}$ NMR of compounds 2 (400MHz, DMSO- $d_{6}$ ) and $\mathbf{3}$ $\left(400 \mathrm{MHz}, \mathrm{CDCl}_{3}\right)$. See the figure S2 in: https://www.raccefyn.co/ index.php/raccefyn/article/downloadSuppFile/822/3774

Figure S3. ${ }^{13} \mathrm{C}-\mathrm{NMR}$ (DMSO- $d_{\sigma}, 101 \mathrm{MHz}$ ) spectrum of 2(4-butylphenyl)-4,6- dihydrazinylpyrimidine (2). See the figure S3 in: https://www.raccefyn.co/index.php/raccefyn/article/download SuppFile/822/3884

Figure S4. ${ }^{~} \mathrm{H}-\mathrm{NMR}$ - NOESY of compound 3 (400 $\left.\mathrm{MHz}, \mathrm{CDCl}_{3}\right)$. See the figure S4 in: https://www.raccefyn.co/index.php/raccefyn/ article/downloadSuppFile/822/3885

Figure S5. ${ }^{13} \mathrm{C}-\mathrm{NMR}\left(\mathrm{CDCl}_{3}, 101 \mathrm{MHz}\right)$ spectrum of Bis (hydrazone) 3. See the figure S5 in: https://www.raccefyn.co/index.php/raccefyn/ article/downloadSuppFile/822/3886

Figure S6. 2D-NMR HSQC $\left(\mathrm{CDCl}_{3}, 400 \mathrm{MHz}\right)$ spectrum of Bis(hydrazone) 3. See the figure S6 in: https://www.raccefyn.co/ index.php/raccefyn/article/downloadSuppFile/822/3887

Figure S7. 2D-NMR COSY $\left(\mathrm{CD}_{3} \mathrm{CN}-d_{3}\right.$., $\left.400 \mathrm{MHz}\right)$ of grid complex $\left[\mathrm{Zn}_{4} \mathrm{~L}_{4}\right] \cdot 8\left(\mathrm{BF}_{4}\right)$. Aromatic region onset. See the figure S7 in: https://www.raccefyn.co/index.php/raccefyn/article/download SuppFile/822/3888 
Rev. Acad. Colomb. Cienc. Ex. Fis. Nat. 43(167):273-283, abril-junio de 2019 doi: http://dx.doi.org/10.18257/raccefyn.822

Figure S8. 2D-NMR COSY $\left(\mathrm{CD}_{3} \mathrm{CN}-d_{3}\right.$, $\left.400 \mathrm{MHz}\right)$ of grid complex $\left[\mathrm{Zn}_{4} \mathrm{~L}_{4}\right] \cdot 8\left(\mathrm{BF}_{4}\right)$. Aliphatic region onset. See the figure $\mathrm{S} 8$ in: https://www.raccefyn.co/index.php/raccefyn/article/download SuppFile/822/3889

Figure S9. 2D-NMR NOESY $\left(\mathrm{CD}_{3} \mathrm{CN}-d_{3}\right.$., $\left.400 \mathrm{MHz}\right)$ of grid complex $\left[\mathrm{Zn}_{4} \mathrm{~L}_{4}\right] \cdot 8\left(\mathrm{BF}_{4}\right)$. Aliphatic region onset. See the figure S9 in: https://www.raccefyn.co/index.php/raccefyn/article/download SuppFile/822/3890

Figure S10. Rotation of the bis(hydrazone) 3 with A) and without B) the presence of the metal cation. On free ligand cisoid conformation is destabilized by the repulsion of the nitrogen lone pairs. See the figure S11 in: https://www.raccefyn.co/index.php/ raccefyn/article/downloadSuppFile/822/3891

Figure S11. UV-Vis Spectra of ligand 3 and Grid like complex $\left[\left(\mathrm{Zn}_{4}(3)_{4}\right]\left(\mathrm{BF}_{4}\right)_{8}\right.$ in methanol. See the figure S10 in: https://www. raccefyn.co/index.php/raccefyn/article/downloadSuppFile/822/3892

Figure S12. Randless-Sevick linear fit for oxidation peaks in (a) bis(hydrazone) (3) and (B) grid complex $\left[\mathrm{Zn}_{4} \mathrm{~L}_{4}\right] \cdot 8\left(\mathrm{BF}_{4}\right)$. See the figure S12 in: https://www.raccefyn.co/index.php/raccefyn/article/ downloadSuppFile/822/3893

Figure S13. Randless-Sevick linear fit for oxidation peaks in (a) bis(hydrazone) (3) and (B) grid complex $\left[\mathrm{Zn}_{4} \mathrm{~L}_{4}\right] \cdot 8\left(\mathrm{BF}_{4}\right)$. See the figure $\mathrm{S} 13$ in: https://www.raccefyn.co/index.php/raccefyn/article/ downloadSuppFile/822/3894

\section{Author contributions}

JDV carried out the electrochemical and the UV Vis experiments and drafted all the results and the manuscript. JL performed the synthesis of compound $\mathbf{3}$ and the grid like complex. M.C analyzed the data, proofread, and reviewed the final document.

\section{Conflicts of interest}

The authors declare that there is no conflict of interest of any kind that could possibly affect the publication or the results of this research process.

\section{References}

Adenier, A., Chehimi, M. M., Gallardo, I., Pinson, J., Vilà, N. (2004). Electrochemical oxidation of aliphatic amines and their attachment to carbon and metal surfaces. Langmuir. 20 (19): 8243-8253. Doi: 10.1021/la049194c

Alam, M. S., Strömsdörfer, S., Dremov, V., Müller, P., Kortus, J., Ruben, M., Lehn, J.-M. (2005). Addressing the Metal Centers of [2×2] CoII4 Grid-Type Complexes by STM/ STS. Angewandte Chemie International Edition. 44 (48): 7896-7900. Doi: 10.1002/anie.200502743

Barboiu, M., Ruben, M., Blasen, G., Kyritsakas, N., Chacko, E., Dutta, M., ... Lehn, J.-M. (2006). Self-Assembly, Structure and Solution Dynamics of Tetranuclear Zn2+ Hydrazone [2×2] Grid-Type Complexes. European Journal of Inorganic Chemistry. 2006 (4): 784-792. Doi: 10.1002/ ejic. 200500963

Biswas, S., Das, S., van Leusen, J., Kögerler, P., Chandrasekhar, V. (2014). Tetranuclear [2×2] Square-Grid Lanthanide(III) Complexes: Syntheses, Structures, and Magnetic Properties. European Journal of Inorganic Chemistry. 2014 (25): 4159-4167. Doi: 10.1002/ejic.201402326
Electronic and electrochemical properties of a grid-like structure of $\mathrm{Zn}$ (II)

Breuning, E., Ruben, M., Lehn, J., Renz, F., García, Y., Ksenofontov, V., ... Rissanen, K. (2000). Spin Crossover in a Supramolecular Fe4II [2×2] Grid Triggered by Temperature, Pressure, and Light. Angewandte Chemie International Edition. 39 (14): 2504-2507. Doi: 10.1002/1521-3773(20000717)39:14<2504::AIDANIE2504>3.0.CO;2-B

Bu, X.-H., Tanaka, K., Shionoya, M., Biradha, K., Morishita, H., Furusho, S. (2000). A spontaneously resolved chiral molecular box: A cyclic tetranuclear ZnII complex with DPTZ (DPTZ = 3,6-di-2-pyridyl-1,2,4,5-tetrazine). Chemical Communications. VOL. (2000) (11): 971-972. Doi: 10.1039/a909742b

Busch, D. H. (1967). Transition Metal Complexes of the new Synthetic Macrocyclic Ligands. Helvetica Chimica Acta. 50 (S1): 174-206. Doi: 10.1002/hlca.19670500914

Campos-Fernández, C. S., Clérac, R., Koomen, J. M., Russell, D. H., Dunbar, K. R. (2001). Fine-Tuning the Ring-Size of Metallacyclophanes: A Rational Approach to Molecular Pentagons. Journal of the American Chemical Society. 123 (4): 773-774. Doi: 10.1021/ja002960r

Carmona-Vargas, C. C., Váquiro, I. Y., Jaramillo-Gómez, L. M., Lehn, J.-M., Chaur, M. N. (2017). Grid-type complexes of $\mathrm{M} 2+(\mathrm{M}=\mathrm{Co}, \mathrm{Ni}$, and $\mathrm{Zn})$ with highly soluble bis(hydrazone)thiopyrimidine-based ligands: Spectroscopy and electrochemical properties. Inorganica Chimica Acta. 468: 131-139. Doi: 10.1016/j.ica.2017.05.002

Chaur-Valencia, M. N., Zuluaga Corrales, H. F., Martínez, G. (2018). Electronic and electrochemical properties of gridtype metal ion complexes $(\mathrm{Fe}+2$ and $\mathrm{Co} 2+)$ with a pyridinepyrimidine-pyridine based bis(hydrazone). Revista Colombiana de Química. 47 (2): 45-53. Doi: 10.15446/rev.colomb. quim.v47n2.66081

Curtis, N. F. (1960). Transition-metal complexes with aliphatic Schiff bases. Part I. Nickel(II) complexes with $\mathrm{N}$-isopropylideneethylenediamine schiff bases. Journal of the Chemical Society (Resumed). 4409-40413. Doi: 10.1039/jr9600004409

Dawe, L. N., Shuvaev, K. V., Thompson, L. K. (2009). Polytopic ligand directed self-assembly_polymetallic $[\mathrm{n} \times \mathrm{n}]$ grids versus non-grid oligomers. Chemical Society Reviews. 38 (8): 2334. Doi: 10.1039/b807219c

Dawe, L. N. \& Thompson, L. K. (2008). Complete and 'incomplete' [2 $\times 2$ ] grids by self-assembly with a sterically hindered ditopic imidazole hydrazone ligand - structural and magnetic studies. Dalton Transactions. 27: 3610. Doi: 10.1039/b800529j

Dietrich-Buchecker, C. O. \& Sauvage, J.-P. (1989). A Synthetic Molecular Trefoil Knot. Angewandte Chemie International Edition in English. 28 (2): 189-192. Doi: 10.1002/ anie. 198901891

Dutta, M., Movassat, M., Brook, D. J. R., Oliver, A., Ward, D. (2011). Molecular motion in zinc hydrazone grid complexes. Supramolecular Chemistry. 23 (9): 632-643. Doi: 10.1080/10610278.2011.593626

Fernández, M. A., Barona, J. C., Polo-Cerón, D., Chaur, M. N. (2015). Estudios fotoquímicos y electroquímicos de complejos lantánidos de 6-(hidroximetil)piridin- 2-carboxaldehído [2-metilpirimidina-4,6-diil] bishidrazona. Revista Colombiana de Química. 43 (1): 5-11. Doi: 10.15446/rev.colomb. quim.v43n1.50540 
García, A. M., Romero-Salguero, F. J., Bassani, D. M., Lehn, J. M., Baum, G., Fenske, D. (1999). Selfassembly and characterization of multimetallic gridtype lead(II) complexes. Chemistry - A European Journal. 5 (6): 1803-1808. Doi: 10.1002/(SICI)15213765(19990604)5:6<1803::AID-CHEM1803>3.0.CO;2-M

Gordillo, M. A., Soto-Monsalve, M., Carmona-Vargas, C. C., Gutiérrez, G., D'Vries, R. F., Lehn, J. M., Chaur, M. N. (2017). Photochemical and Electrochemical Triggered Bis(hydrazone) Switch. Chemistry - A European Journal. 23 (59): 14872-14882. Doi: 10.1002/chem.201703065

Hanan, G. S., Volkmer, D., Schubert, U. S., Lehn, J. M., Baum, G., Fenske, D. (1997). Coordination arrays: Tetranuclear cobalt(II) complexes with $\left[\begin{array}{lll}2 & \mathrm{x} & 2\end{array}\right]$-grid structure. Angewandte Chemie - International Edition in English. 36 (17): 1842-1844. Doi: 10.1002/anie.199718421

Hardy, J. G. (2013). Metallosupramolecular grid complexes: Towards nanostructured materials with high-tech applications. Chemical Society Reviews. 42 (19): 7881. Doi: $10.1039 / \mathrm{c} 3 \mathrm{cs} 60061 \mathrm{k}$

Harrowfield, J. \& Lehn, J. (2012). ChemInform Abstract: Multifunctionality and Multivalency Generation by Selfassembly of Grid-type Metallosupramolecular Architectures. ChemInform. 43 (28): 170-173. Doi: 10.1002/ chin. 201228260

Hasenknopf, B., Lehn, J. M., Boumediene, N., Dupont-Gervais, A., Van Dorsselaer, A., Kneisel, B., Fenske, D. (1997). Self-assembly of tetra- and hexanuclear circular helicates. Journal of the American Chemical Society. 119 (45): 10956-10962. Doi: 10.1021/ja971204r

Lehn, J.-M. (1988). Supramolecular Chemistry-Scope and Perspectives Molecules, Supermolecules, and Molecular Devices(Nobel Lecture). Angewandte Chemie International Edition in English. 27 (1): 89-112. Doi: 10.1002/ anie. 198800891

Lehn, J.-M. (2006). Molecular and Supramolecular Devices. Supramolecular Chemistry. p. 89-138. Weinheim, FRG: Wiley-VCH Verlag GmbH \& Co. KGaA. Doi: 10.1002/3527607439.ch8

Nobelprize.org. (2016). The Nobel Prize in Chemistry 2016 - Advanced Information. Accessed on: December 20, 2018. Available from: https://www.nobelprize.org/prizes/ chemistry/2016/advanced-information/

Parween, A., Naskar, S., Mota, A. J., Espinosa Ferao, A., Chattopadhyay, S. K., Rivière, E., ... Naskar, S. (2017). C i -Symmetry, [2 $\times 2$ ] grid, square copper complex with the $\mathrm{N} 4$, N 5 -bis(4-fluorophenyl)-1H-imidazole-4,5-dicarboxamide ligand: Structure, catecholase activity, magnetic properties and DFT calculations. New Journal of Chemistry. 41 (20): 11750-11758. Doi: 10.1039/C7NJ01667K

Rojo, Z., Romero-Salguero, F.-J., Lehn, J.-M., Baum, G., Fenske, D. (1999). Self-Assembly, Structure, and Physical Properties of Tetranuclear ZnII and CoII Complexes of [2 $\mathrm{x}$ 2] Grid-Type. European Journal of Inorganic Chemistry. 1999: 1421-1428. Doi: 10.1002/ (SICI) 1099-0682(199909)1999:9\%3C 1421::AIDEJIC1421\%3E3.0.CO;2-J

Ruben, M., Breuning, E., Gisselbrecht, J. P., Lehn, J. M. (2000). Multilevel molecular electronic species: Electrochemical reduction of a [2 x 2] Co4/(II) grid-type complex by 11 electrons in 10 reversible steps. Angewandte
Chemie - International Edition. 39 (22): 4139-4142. Doi: 10.1002/1521-3773(20001117)39:22<4139::AIDANIE4139>3.0.CO;2-Y

Ruben, M., Breuning, E., Lehn, J.-M., Ksenofontov, V., Renz, F., Gütlich, P., Vaughan, G. B. M. (2003). Supramolecular Spintronic Devices: Spin Transitions and Magnetostructural Correlations in[Fe4IIL4]8+[2×2]-Grid-Type Complexes. Chemistry - A European Journal. 9 (18): 4422-4429. Doi: 10.1002/chem.200304933

Ruben, M., Lehn, J.-M., Müller, P. (2006). Addressing metal centres in supramolecular assemblies. Chem. Soc. Rev. 35 (11): 1056-1067. Doi: 10.1039/B517267P

Ruben, M., Lehn, J., Vaughan, G. (2003). Synthesis of ionisable $[2 \times 2]$ grid-type metallo-arrays and reversible protonic modulation of the optical properties of the [CoII4L 4 ] 8+ species. Chem. Commun. 3 (12): 1338-1339. Doi: 10.1039/ B303922F

Ruben, M., Rojo, J., Romero-Salguero, F. J., Uppadine, L. H., Lehn, J.-M. (2004). Grid-Type Metal Ion Architectures: Functional Metallosupramolecular Arrays. Angewandte Chemie International Edition. 43 (28): 3644-3662. Doi: 10.1002/anie. 200300636

Shen, F., Huang, W., Wu, D., Zheng, Z., Huang, X.-C., Sato, O. (2016). Redox Modulation of Spin Crossover within a Cobalt Metallogrid. Inorganic Chemistry. 55 (2): 902-908. Doi: 10.1021/acs.inorgchem.5b02442

Stadler, A.-M., Ramírez, J., Lehn, J.-M., Vincent, B. (2016). Supramolecular reactions of metallo-architectures: $\mathrm{Ag}$ 2 -double-helicate/Zn 4 -grid, $\mathrm{Pb} 4$-grid/Zn 4 -grid interconversions, and $\mathrm{Ag} 2$-double-helicate fusion. Chemical Science. 7 (6): 3689-3693. Doi: 10.1039/ C5SC04403K

Stadler, A. M., Kyritsakas, N., Graff, R., Lehn, J. M. (2006). Formation of rack- And grid-type metallosupramolecular architectures and generation of molecular motion by reversible uncoiling of helical ligand strands. Chemistry - A European Journal. 12 (17): 4503-4522. Doi: 10.1002/ chem.200501202

Stefankiewicz, A. R., Harrowfield, J., Madalan, A. M., Lehn, J.-M. (2013). Tuning the planarity of $[2 \times 2]$ grids. CrystEngComm. 15 (44): 9128. Doi: 10.1039/c3ce41510d

Stefankiewicz, A. R., Rogez, G., Harrowfield, J., Drillon, M., Lehn, J.-M. (2009). Structural features directing the specificity and functionality of metallo-supramolecular grid-type architectures. Dalton Transactions. 29: 5787. Doi: 10.1039/b902262g

Stefankiewicz, A. R., Wałęsa-Chorab, M., Szcześniak, H. B., Patroniak, V., Kubicki, M., Hnatejko, Z., Harrowfield, J. (2010). Grid-corner analogues: Synthesis, characterisation and spectroscopic properties of meridional complexes of tridentate NNO Schiff-base ligands. Polyhedron. 29 (1): 178-187. Doi: 10.1016/j.poly.2009.06.069

Thompson, L. K., Waldmann, O., Xu, Z. (2005). Polynuclear manganese grids and clusters - A magnetic perspective. Coordination Chemistry Reviews. 249 (23): 2677-2690. Doi: 10.1016/j.ccr.2005.07.002

Uppadine, L. H., Gisselbrecht, J. P., Kyritsakas, N., Nättinen, K., Rissanen, K., Lehn, J. M. (2005). Mixed-valence, mixed-spin-state, and heterometallic [2×2] grid-type arrays based on heteroditopic hydrazone ligands: Synthesis and electrochemical features. Chemistry - A European Journal. 11 (8): 2549-2565. Doi: 10.1002/chem.200401224 
Wang, S., Men, G., Zhao, L., Hou, Q., Jiang, S. (2010). Binaphthyl-derived salicylidene Schiff base for dualchannel sensing of $\mathrm{Cu}, \mathrm{Zn}$ cations and integrated molecular logic gates. Sensors and Actuators, B: Chemical. 145 (2): 826-831. Doi: 10.1016/j.snb.2010.01.060

Wasserman, E. (1960). the Preparation of Interlocking Rings: a Catenane1. Journal of the American Chemical Society. 82 (16): 4433-4434. Doi: 10.1021/ja01501a082

Wu, S. Q., Wang, Y. T., Cui, A. L., Kou, H. Z. (2014). Toward higher nuclearity: Tetranuclear cobalt(II) metallogrid exhibiting spin crossover. Inorganic Chemistry. 53 (5): 2613-2618. Doi: 10.1021/ic402971a
Youinou, M.-T., Rahmouni, N., Fischer, J., Osborn, J. A. (1992). Self-Assembly of a Cu4 Complex with Coplanar Copper(I) Ions: Synthesis, Structure, and Electrochemical Properties. Angewandte Chemie International Edition in English. 31 (6): 733-735. Doi: 10.1002/anie.199207331

Yu, F., Hou, L. J., Qin, L. Y., Chao, J. Bin, Wang, Y., Jin, W. J. (2016). A new colorimetric and turn-on fluorescent chemosensor for $\mathrm{Al}^{3+}$ in aqueous medium and its application in live-cell imaging. Journal of Photochemistry and Photobiology A: Chemistry. 315: 8-13. Doi: 10.1016/j. jphotochem.2015.09.006 